\title{
PENGARUH INSENTIF, SARANA PENDUKUNG, DAN KOMPETENSI SUMBER DAYA MANUSIA TERHADAP MOTIVASI KERJA PEGAWAI PT. ANGKASA PURA II (PERSERO) UNIT ARFF BANDAR UDARA INTERNASIONAL KUALANAMU
}

\author{
Hasrudy Tanjung ${ }^{1)}$, Kurnia Bakti ${ }^{1)}$ *, Zulaspan Tupti ${ }^{1)}$ \\ 1) Program Studi Magister Manajemen, Universitas Muhammadiyah Sumatera Utara \\ *Penulis Korespondensi: kurnie87@gmail.com
}

\begin{abstract}
Abstrak
Penelitian ini bertujuan untuk menguji pengaruh insentif, sarana pendukung dan kompetensi SDM terhadap motivasi kerja. Jumlah responden yang dilibatkan dalam penelitian ini adalah sebanyak 74 responden. Seluruh responden merupakan pegawai yang terdapat pada kantor unit ARFF Bandar Udara Internasional Kualanamu. Penelitian ini merupakan penelitian dengan pendekatan kuantitatif yang menggunakan nstrument berupa angket kuesioner. Data hasil penelitian dianalisis dengan menggunakan teknik analisis Partial Least Square dengan bantuan program Smartpls3.0.Berdasarkan hasil analisis dalam penelitian ini diperoleh beberapa hasil sebagai berikut : (1) Insentif berpengaruh positif dan signifikan terhadap motivasi kerja, semakin baik pemberian insentif pegawai maka semakin tinggi motivasi kerja pegawai; (2) Sarana pendukung berpengaruh positif dan signifikan terhadap motivasi kerja, semakin baik sarana pendukung yang disediakan bagi pegawai maka semakin tinggi motivasi kerja pegawai; (3)Kompetensi SDM berpengaruh positif dan signifikan terhadap motivasi kerja, semakin baik kompetensi pegawai maka semakin tinggi motivasi kerja pegawai; (4) Insentif, sarana pendukung dan kompetensi SDM berpengaruh secara simultan terhadap motivasi kerja pegawai dengan besar konstribusi sebesar $81,3 \%$.
\end{abstract}

Keywords: insentif, sarana pendukung, kompetensi SDM, motivasi kerja, partial least square

Article Information:

Received Date: 8 Desember 2021

Revised Date: 16 Desember 2021

Accepted Date: 4 Januari 2022 


\section{PENDAHULUAN}

Bandar udara Internasional Kualanamu merupakan Bandar Udara komersil yang dikelola oleh PT. Angkasa Pura II (Persero). PT. Perusahaan yang bergerak di sektor pelayanan kebandar udaraan ini memberikan banyak kontribusi terhadap perekonomian Indonesia. Namun, sejak ditetapkannya Corona Virus Desease 2019 (Covid-19) sebagai pandemi oleh World Health Organization (WHO) di awal tahun 2020 PT. Angkasa Pura II (Persero) merupakan salah satu perusahaan yang terkena dampak cukup besar. Pembatasan penerbangan keluar dan masuk wisatawan lokal maupun asing di Indonesia menyebabkan semua banda udara yang dikelolanya mengalami penurunan jumlah penerbangan sehingga akibatnya terjadi penurunan pendapatan perusahaan tersebut.

Pendapatan yang berkurang cukup drastis ini menyebabkan PT. Angkasa Pura II melakukan penghematan melalui penyesuaian fasilitas di Bandar Udara dengan pergerakan penumpang dan biaya operasional seperti pembatasan operasi. Organisasi PKP-PK (Pertolongan Kecelakaan Penerbangan dan Pemadam Kebakaran) yang sekarang disebut unit ARFF (Airport Rescue and Fire Fighting) merupakan bagian dari PT. Angkasa Pura II yang juga terkena dampak dari penekanan operational cost. Persentase berkurangnya pendapatan terlihat dari tidak tercapainya target RKAP (Rencana Kerja dan Anggaran Perusahaan) periode Desember 2020.

Berdasarkan hasil observasi yang dilakukan pada bulan Januari tahun 2021 diperoleh informasi bahwa pencapaian pendapatan usaha $58 \%$ di bawah target RKAP per 31 Desember 2020. Beban usaha perusahaan per Desember 2020 yaitu $21 \%$ di bawah target RKAP. Hal ini menunjukkan bahwa jumlah biaya yang dikeluarkan untuk beban usaha lebih besar pencapaian targetnya daripada pendapatan. Berdasarkan hal tersebut perusahaan harus melakukan penekanan biaya dari setiap bidang termasuk unit ARFF.
Peneka/nan biaya oleh PT. Angkasa Pura II (Persero) salah satunya dilakukan terhadap pemberian insentif pegawai. Insentif adalah imbalan langsung yang diberikan kepada pegawai sebagai bentuk apresiasi atas kinerja yang melebihi standar yang telah ditentukan (Sopiah dan Sangadji, 2018). Bentuk pemberian insentif oleh PT. Angkasa Pura II (Persero) khususnya di unit ARFF biasanya terdiri dari gaji dasar pensiun, penunjang gaji dasar, tunjangan jabatan, tunjangan dan benefit, tunjangan uang makan, tunjangan license dan / atau rating, insentif produksi, tunjangan cuti, tunjangan kesejahteraan keluarga, tunjangan hari raya keagamaan, sumbangan uang sewa rumah dan tunjangan perumahan akhir masa tugas, sumbangan perkawinan, sumbangan kelahiran dan sumbangan kematian, tunjangan hari tua dan manfaat pensiun, bantuan biaya ke tempat menjalani masa pensiun. Beberapa insentif tersebut mengalami pengurangan jumlah bahkan ada yang ditiadakan.

Unit ARFF Bandar Udara Internasional Kualanamu tidak terlepas dari sarana pendukung dalam menjalankan operasional pekerjaanya. Sarana pendukung yang diperlukan oleh unit ARFF Bandar Udara Internasional Kualanamu adalah kendaraan utama, kendaraan pendukung, peralatan pendukung serta peralatan penunjang. Selama terjadinya pandemi Covid-19 sarana pendukung tersebut juga mengalami beberapa permasalahan, seperti pemeliharaanya yang kurang maksimal. Selain pemeliharaan, beberapa sarana pendukung juga penggunaannya kurang efektif karena kurangnya personel yang memiliki lisensi dalam pelaksanaannya.

Selain insentif dan sarana pendukung kegiatan operasi seperti latihan atau diklat untuk peningkatan kompetensi sumber daya manusia (SDM) di unit ARFF Bandar Udara Internasional Kualanamu saat ini dilakukan tidak lagi secara flisik/turun ke lapangan melainkan melalui daring (virtual zoom meeting). Padahal SDM atau pegawai unit 
ARFF ini dituntut harus memiliki kompetensi yang berkaitan dengan penyelamatan pertolongan kecelakaan penerbangan serta pemadam kebakaran di bandar udara dan sekitarnya.

Kompetensi adalah karakteristik dasar seseorang (individu) yang mempengaruhi cara berpikir dan bertindak, membuat generalisasi terhadap segala situasi yang dihadapi serta bertahan cukup lama dalam diri manusia (Elizar dan Tanjung, 2018). Kompetensi juga merupakan salah satu kunci dalam manajemen sumber daya manusia (Sopiah dan Sangadji, 2018). Unit ARFF dituntut harus memiliki kompetensi sebagai berikut mampu mengoperasikan komputer sekurangkurangnya program pengolahan data dan angka, memahami dan mampu mengaplikasikan prosedur pelayanan darurat, menyiapkan standar prosedur operasi ARFF, menyiapkan standar prosedur latihan dan kendali mutu ARFF serta pencegahan bahaya kebakaran, menyiapkan standar prosedur pemeliharaan kendaraan dan peralatan ARFF, melaksanakan bimbingan unit ARFF (Direktur Jenderal Perhubungan Udara, 2012).

Penyelenggara Bandar Udara harus mempertahankan organisasasi unit ARFF sesuai dengan struktur manajemen yang baik dan efektif serta dikaitkan dengan keberadaan dan kondisi pelayanan yang diberikan. Permasalahan seperti insentif, sarana pendukung dan kompetensi SDM tersebut kemungkinan dapat mempengaruhi motivasi kerja pegawainya. Padahal berdasarkan pentingnya peran dari unit ARFF di perusahaan maka SDM nya dituntut untuk memiliki motivasi kerja yang baik. Motivasi kerja adalah sebuah proses dari intensitas karyawan, arahan dan ketekunan sebagai upaya mencapai tujuan organisasi (Sumardjo dan Priansa, 2018). Definisi tersebut menunjukkan bahwa ada tiga elemen dari motivasi, yaitu kebutuhan, dorongan, dan insentif (Suparyadi, 2015). Faktor yang mempengaruhi motivasi kerja seseorang, yaitu motivasi intrinsik (minat, sikap positif dan kebutuhan); dan motivasi ekstrinsik terdiri dari motivator dan kesehatan kerja (Sumardjo dan Priansa, 2018). Hasil observasi di lapangan motivasi kerja pegawai PT. Angkasa Pura II (Persero) khususnya di unit ARFF mengalami penurunan. Hal tersebut terlihat dari adanya beberapa pegawai yang kurang peduli dan peka terhadap pekerjaan, serta bekerja hanya mendapatkan teguran dari atasannya saja. Penurunan motivasi tersebut dapat dikaitkan dengan adanya pengurangan sejumlah insentif dan terbatasnya kuota untuk mengajukan promosi jabatan sehingga pegawai merasa tidak semangat untuk menunjukkan eksistensi atau semangat kerjanya.

Berdasarkan masalah-masalah yang telah diuraikan di atas maka perlu dilakukannya penelitian "Pengaruh Insentif, Sarana Pendukung, dan Kompetensi Sumber Daya Manusia Terhadap Motivasi Kerja Pegawai PT. Angkasa Pura II (Persero) Unit ARFF Bandar Udara Internasional Kualanamu". Penelitian ini bertujuan untuk melihat hubungan/pengaruh antar variabel tersebut di masa pandemi Covid-19.

\section{TINJAUAN PUSTAKA}

Insentif adalah segala sesuatu yang dapat memenuhi kebutuhan individu, sehingga untuk memperoleh keseimbangan fisiologis, psikologis dan sosiologis maka insentif juga harus diperoleh (Suparyadi, 2015). Definisi lainnya dari insentif yaitu imbalan langsung yang diberikan perusahaan kepada pegawai yang memiliki kinerja melebihi standar yang ditentukan (Sopiah \& Sangadji, 2018). Insentif juga merupakan alat untuk mendorong karyawan agar lebih meningkatkan produktivitas kerja untuk mencapai tujuan perusahan yang telah ditetapkan (Kusuma \& Mashariono, 2016).

Berdasarkan definisi-definisi yang telah dikemukakan di atas dapat diambil kesimpulan bahwa insentif adalah suatu balas jasa ataupun pemberian yang diberikan oleh perusahaan atau institusi tempat bekerja terhadap pegawai yang telah mampu 
menunjukkan kinerja yang sesuai dengan apa yang diinginkan oleh perusahaan. Adanya kemajuan terhadap perusahaan sebagai bentuk usaha atau hasil kinerja pegawainya patut diberikan kompensasi berupa insentif.

Bentuk-bentuk insentif yang diberikan

PT. Angkasa Pura II (Persero) kepada pegawainya, yaitu tunjangan jabatan, tunjangan dan benefit, tunjangan uang makan, tunjangan lisensi, tunjangan cuti, tunjangan produksi, tunjangan kesejahteraan keluarga, tunjangan hari raya keagamaan dan sebagainya (Dirjend Pembinaan Hubungan Industrial dan Jaminan Sosial Tenaga Kerja, 2018). Insentif pada penelitian ini dibatasi pada tunjangan uang makan. Indikatorindikator insentif pada penelitian ini mengikuti lima poin berikut, yaitu (Kusuma, 2016): 1) Kinerja, 2) Lama kerja, 3) Senioritas, 4) Kebutuhan, 5) Keadilan dan kelayakan. Indikator tersebut diukur melalui pemberian kuesioner.

Sarana adalah
segala jenis
peralatan, perlengkapan
kerja dan
fasilitas yang berfungsi
utama/ pebagai alat
pekerjaan, dan juga dalam rangka
kepentingan yang sedang berhubungan dengan organisasi kerja (Moenir, 2016). Pengertian yang tersebut jelas memberi arah bahwa sarana dan prasarana adalah merupakan seperangkat alat yang digunakan dalam suatu proses kegiatan baik alat tersebut adalah merupakan peralatan pembantu maupun peralatan utama, yang keduanya berfungsi untuk mewujudkan tujuan yang hendak dicapai. Sarana pendukung yang dimaksud dalam penelitian ini adalah sarana yang harus dimiliki oleh unit ARFF untuk mendukung kinerja dalam penyelamatan dan pemadam kebakaran Bandar Udara Interasional Kualanamu. Sarana yang harus dimiliki unit ARFF Bandar Udara Internasional Kualanamu menurut Direktur Jenderal Perhubungan Udara
(2015), yaitu: 1) Kendaraan pertolongan; 2) Bahan pemadam; 3) Pakaian pemadam; 4) Peralatan bantu pernapasan; dan 5) Peralatan pendukung.

Kompetensi Sumber Daya Manusia adalah suatu kemampuan yang dimiliki oleh seseorang sehingga membentuk satu karakteristik diri dan menjadi perilaku yang diperlukan untuk menjadi suatu kinerja yang diharapkan sehingga dalam kategori kinerja menjadi baik dan dalam proses penyelesaiaanya dapat terlaksana secara profesional, efektif, dan efisien.

Seorang pegawai yang berkompeten dapat dilihat dari pengetahuannya, keterampilan kerjanya, konsep diri yang dimiliki, ciri diri dan motif (Pattiasina et al., 2016). Namun, pada penelitian ini indikator kompetensi SDM yang digunakan, yaitu: 1. Inisiatif; 2. Berpikir analitik; 3. Keahlian praktikal; 4. Pengendalian diri; dan 5. Kerja tim (Sugiyanto \& Santoso, 2018).

Pegawai bekerja karena memiliki motif. Motif tersebut berkait dengan maksud atau tujuan yang ingin diraihnya. Pada umumnya, motif utama pegawai untuk bekerja adalah mencari penghasilan, mengembangkan potensi diri, aktualisasi, serta kebutuhan akan penghargaan. Kreitner dan Kinicki (dalam Sumardjo dan Priansa; 2018) menyatakan bahwa motivasi kerja adalah proses psikologi yang ditampilkan melalui perilaku. Sedangkan menurut Wood et.al. (dalam Sumardjo dan Priansa; 2018) menyatakan bahwa motivasi kerja menggambarkan kekuatan individu yang menjelaskan bagaimana tingkat, arah, serta upaya yang dilakukannya. Berdasarkan definisi-definisi di atas dapat disimpulkan bahwa motivasi kerja merupakan proses yang menunjukkan intensitas individu, arah, dan ketekunan sebagai upaya mencapai tujuan organisasi.

Ada beberapa teori atau sumber yang mengungkapkan indikator-indikator dari motivasi kerja. Motivasi kerja dapat dilihat dari beberapa indikator, seperti perilaku karyawan, usaha karyawan, dan kegigihan 
karyawan (Changgriawan, 2017). Selain itu ada juga yang mengungkapkan indikator untuk mengetahui motivasi kerja karyawan, yaitu: 1 . Tanggung jawab; 2. Keberhasilan; 3. Peluang untuk maju; 4. Pengakuan atas kinerja; 5. Tantangan kinerja; 6. Dukungan atasan; dan 7. Kinerja. Indikator motivasi kerja yang digunakan dalam penelitian ini, yaitu: 1 . Tanggung jawab; 2. Prestasi kerja; 3. Peluang untuk Maju; 4. Pengakuan atas kinerja; dan 5. Pekerjaan yang menantang (McClelland dalam Sedarmayanti, dkk., 2020).

\section{METODE PENELITIAN}

Penelitian ini dilaksanakan di kantor unit ARFF Bandar Udara Internasional Kualanamudan dilaksanakan mulai bulan Januari 2021 sampai dengan September 2021. Populasi dalam penelitian ini adalah seluruh pegawai yang terdapat pada kantor unit ARFF Bandar Udara Internasional Kualanamu bagian operasional yang berjumlah 74 orang. Sampel yang digunakan merupakan total sampling sehingga jumlah sampel sama dengan jumlah populasi yaitu 74 orang pegawai.

Terdapat empat variabel yang diteliti, yaitu Motivasi kerja, insentif, sarana pendukung, dan kompetensi SDM. Definisi dan indikator dari masing-masing variabel dapat dilihat pada Tabel 1.

Tabel 1. Definisi dan Indikator dari Variabel Penelitian

\begin{tabular}{|c|c|c|}
\hline & perusahaan. & $\begin{array}{l}\text { - Keadilan dan } \\
\text { kelayakan }\end{array}$ \\
\hline $\begin{array}{l}\text { Sarana } \\
\text { Pendukun } \\
\mathrm{g}(\mathrm{X} 2)\end{array}$ & $\begin{array}{lr}\text { segala } & \text { jenis } \\
\text { peralatan, } & \\
\text { perlengkapan } & \text { kerja } \\
\text { dan fasilitas yang } \\
\text { berfungsi sebagai } \\
\text { alat pendukung } \\
\text { pelaksanaan } \\
\text { pekerjaan. }\end{array}$ & $\begin{array}{l}\text { - Kendaraan } \\
\text { pertolongan } \\
\text { - Bahan pemadam } \\
\text {-Pakaian } \\
\text { pelindung } \\
\text {-Peralatan bantu } \\
\text { pernapasan } \\
\text { - Peralatan } \\
\text { pendukung }\end{array}$ \\
\hline $\begin{array}{l}\text { Kompeten } \\
\text { si SDM } \\
\text { (X3) }\end{array}$ & $\begin{array}{l}\text { kapasitas seseorang } \\
\text { yang membuat orang } \\
\text { tersebut mampu } \\
\text { memenuhi apa yang } \\
\text { disyaratkan oleh } \\
\text { pekerjaan dalam } \\
\text { suatu organisasi } \\
\text { sehingga mencapai } \\
\text { hasil sesuai. harapan }\end{array}$ & $\begin{array}{l}\text { - Inisiatif } \\
\text { - Berpikir analitik } \\
\text { - Keahlian } \\
\text { praktikal } \\
\text { - Pengendalian diri } \\
\text { - Kerja tim }\end{array}$ \\
\hline
\end{tabular}

Pengumpulan data yang berhubungan dengan variabel penelitian dilakukan secara langsung yaitu melalui metode kuesioner. Skala yang dipakai dalam penyusunan adalah skala Likert. Dalam Pengkurannya, setiap responden diminta pendapatnya mengenai suatu pertanyaan dengan skala: sangat sesuai, sesuai, netral, tidak sesuai, dan sangat tidak sesuai.

Tahap analisis dalam penelitian ini meliputi beberapa tahap, yaitu : (1) Tahap Analisis Deskriptif Karakteristik responden; dan (2) Tahap Analisis SEM PLS yang digunakan untuk menguji hipotesis dalam penelitian ini.

\begin{tabular}{|c|c|c|}
\hline Variabel & efinisi & Indikator \\
\hline $\begin{array}{l}\text { Motivasi } \\
\text { Kerja (Y) }\end{array}$ & $\begin{array}{lr}\text { dorongan } & \text { untuk } \\
\text { pegawai agar } & \text { bisa } \\
\text { bekerja } & \text { secara } \\
\text { maksimal } & \text { dan } \\
\text { menciptakan } & \\
\text { produktivitas } & \text { yang } \\
\text { tinggi dalam pekerjaan }\end{array}$ & $\begin{array}{l}\text { - Tanggung HASIL DAN PEMBAHASAN } \\
\text { jawab } \\
\text { - Prestasi kerja Hasil Penelitian } \\
\text { - Peluang untuk Karakteristik responden pada } \\
\text { maju penelitian ini terdiri dari sub unit kerja, } \\
\text { - Pengakuan atas sertifikat kompetensi, dan masa kerja. Berikut } \\
\text { kinerja deskripsi dari setiap karakteristik responden. } \\
\text { - Pekerjaan yang Responden dalam penelitian ini adalah } \\
\text { menantang pegawai unit ARFF di Bandar Udara }\end{array}$ \\
\hline $\begin{array}{l}\text { Insentif } \\
\text { (X1) }\end{array}$ & \begin{tabular}{lr} 
alat & \multicolumn{2}{r}{ pendorong } \\
pegawai agar lebih \\
meningkatkan \\
produktivitas \\
untuk mencapai tujuan \\
\end{tabular} & $\begin{array}{l}\text { Internasional Kualanamu yang terdiri dari tiga } \\
\text { sub unit kerja. Jumlah responden berdasarkan } \\
\text { karakteristik sub unit kerja dapat dilihat pada }\end{array}$ \\
\hline
\end{tabular}


Tabel 2. Responden terbanya berasal dari sub unit RFF Operation.

\section{Tabel 2 Karakteristik Sub Unit Kerja}

\begin{tabular}{rlrr}
\hline No & \multicolumn{1}{c}{ Sub Unit } & Jumlah & \multicolumn{1}{c}{$\%$} \\
\hline 1 & RFF Operation & 68 & 91,89 \\
& RFF Exercise \& & & \\
2 & Facility & 4 & 5,41 \\
3 & RFF Quality Inspector & 2 & 2,70 \\
\hline & Jumlah & 74 & 100,00 \\
\hline
\end{tabular}

Berdasarkan sertifikat kompetensi, responden pada penelitian ini dibagi menjadi tiga (basic, junior, dan senior). Jumlah responden berdasarkan sertifikat kompetensi dapat dilihat pada Tabel 4.2.

Tabel 3 Karakteristik Sertifikat Kompetensi

\begin{tabular}{clrr}
\hline No & Kompetensi & Jumlah & \multicolumn{1}{c}{$\%$} \\
\hline 1 & Basic & 19 & 25,68 \\
2 & Junior & 22 & 29,73 \\
3 & Senior & 33 & 44,59 \\
\hline & Jumlah & 74 & 100 \\
\hline
\end{tabular}

Dari tabel diatas menjelaskan

bahwa responden dengan sertifikat kompetensi basic sebanyak 19 responden, dengan sertifikat kompetensi junior sebanyak 22 responden dan sertifikat kompetensi senior sebanyak 33 responden.

Responden sebagian besar memiliki masa kerja enam hingga 10 tahun. Daftar responden berdasarkan masa kerja dapat dilihat pada Tabel 4 berikut ini.

Tabel 4 Karakteristik Masa Kerja

\begin{tabular}{clrr}
\hline No & Masa Kerja & Jumlah & \multicolumn{1}{c}{$\%$} \\
\hline 1 & $1-5$ tahun & 16 & 21,62 \\
2 & $6-10$ tahun & 50 & 67,57 \\
3 & $11-20$ tahun & 5 & 6,76 \\
4 & $>20$ tahun & 3 & 4,05 \\
\hline & Jumlah & 74 & 100 \\
\hline
\end{tabular}

Pengujian hipotesis dalam penelitian ini dilakukan dengan menggunakan teknik analisis Partial Least Square (PLS) dengan bantuan program Smartpls 3.0. Tahap - tahap dalam analisis PLS ini meliputi (1) Tahap pengujian outer model dan (2) Tahap pengujian inner model. pada tahap pengujian outer model, dilakukan pengujian terhadap validitas dan reliabilitas konstruk seluruh indikator dalam model sedangkan pada tahap inner model, akan dilakukan pengujian hipotesis berdasarkan nilai signifikansi dan koefisien jalur antara variabel eksogen dan endogen.

\section{Pengujian Outer Model}

Tahap pengujian model pengukuran meliputi pengujian Convergent Validity, Discriminant Validity dan Composite Reliability. Hasil analisis PLS dapat digunakan untuk menguji hipotesis penelitian jika seluruh indikator dalam model PLS telah memenuhi syarat validitas konvergen, validitas deskriminan dan reliabilitas komposit.

a. Pengujian Validitas Konvergen

Uji validitas konvergen dilakukan dengan melihat nilai loading factor masingmasing indikator terhadap konstruknya. Oleh karena penelitian ini merupakan penelitian konfirmatori, maka batas loading factor yang digunakan adalah sebesar 0,7.

Hasil estimasi model PLS dapat dilihat pada Gambar1. Berdasarkan Gambar 1, bahwa seluruh indikator telah memiliki nilai loading factor $>0,7$. Hal ini menunjukkan bahwa seluruh indikator dapat digunakan sebagai pengukur variabel dalam model PLS ini.

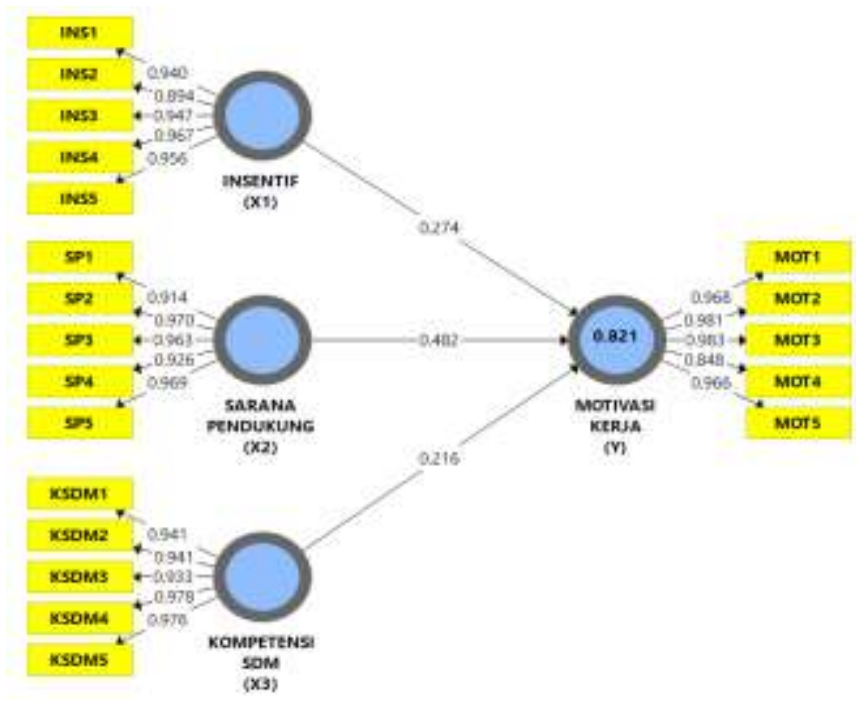

\section{Gambar 1. Hasil estimasi model PLS dengan teknik algorithm}


Selain dengan melihat nilai loading factor masing-masing indikator, validitas konvergen juga harus dinilai dari nilai AVE masing-masing konstruk, seluruh konstruk dalam model PLS dinyatakan telah memenuhi validitas konvergen jika nilai AVE masingmasing konstruk > 0,5. Nilai AVE masingmasing konstruk selengkapnya dapat dilihat pada tabel 5 berikut :

Tabel 5 Nilai Loading Factor dan AVE

\begin{tabular}{|c|c|c|c|c|c|}
\hline Variabel & Insikator & $\begin{array}{c}\text { Loading } \\
\text { Factor }\end{array}$ & $\mathbf{V E}$ & $\begin{array}{l}\text { Validitas } \\
\text { Konvergen }\end{array}$ & tabel di atas menunjukkan \\
\hline \multirow{5}{*}{$\begin{array}{l}\text { Insentif } \\
(\mathbf{X 1})\end{array}$} & JS1 & 0.940 & \multirow{5}{*}{0.886} & Valid & \\
\hline & & & & & memenuhi \\
\hline & 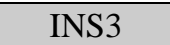 & 47 & & Valid & deskriminan yang dipersyaratkan, sebagai \\
\hline & & & & & contoh variabel MOT (motivasi kerja) \\
\hline & & & & & liki nilai akar kuadrat AVE sebesar \\
\hline \multirow{5}{*}{$\begin{array}{l}\text { Kompetensi } \\
\text { SDM (X2) }\end{array}$} & & & \multirow{5}{*}{0.911} & & 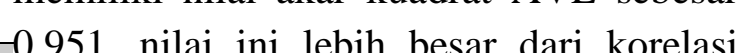 \\
\hline & & & & & \\
\hline & $\mathrm{K}$ & & & & MOT dengan konstruk lain (sebesar 0,83 \\
\hline & $\mathrm{K}$ & & & & terhadap konstruk INS, sebesar 0,797 \\
\hline & & & & & terhadap konstruk KSDM dan sebesar \\
\hline \multirow{5}{*}{$\begin{array}{c}\text { Sarana } \\
\text { Pendukung } \\
\text { (X3) }\end{array}$} & & & \multirow{5}{*}{0.904} & & 0,870 terhadap konstruk SP) sel \\
\hline & & & & & \\
\hline & SP3 & 53 & & & $s 1$ \\
\hline & SP4 & 26 & & & 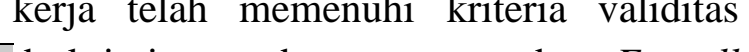 \\
\hline & & & & & Fornell \\
\hline \multirow{4}{*}{$\begin{array}{l}\text { Motivasi } \\
\text { Kerja (Y) }\end{array}$} & $\mathrm{N}$ & 8 & \multirow{5}{*}{0.900} & & \\
\hline & $\mathrm{N}$ & 1 & & - & Selain dengan menggunakan metode \\
\hline & $\mathrm{MO}$ & 983 & & $\mathrm{Va}$ & ll Larcker, validitas deskriminan \\
\hline & MOT4 & 0.848 & & $\mathrm{~V}$ & apat dilihat dari nilai cross $l$ \\
\hline \multirow{7}{*}{\multicolumn{5}{|c|}{$\begin{array}{l}\text { Berdasarkan hasil analisis PLS pada } \\
\text { tabel di atas, nilai AVE seluruh konstruk } \\
\text { baik yang berupa dimensi maupun variabel } \\
\text { telah melebihi } 0,5 \text { yang menunjukkan } \\
\text { bahwa seluruh indikator pada masing- } \\
\text { masing konstruk telah memenuhi kriteria } \\
\text { validitas konvergen yang disyaratkan. } \\
\text { Pengujian Validitas Deskriminan }\end{array}$}} & indikator \\
\hline & & & & & konstruknya, \\
\hline & & & & & memenuhi kriteria validitas deskriminan \\
\hline & & & & & jika cross loading indikator terhadap \\
\hline & & & & & $\begin{array}{l}\text { konstruknya lebih tinggi dibandingkan } \\
\text { dengan nilai cross loading indikator }\end{array}$ \\
\hline & & & & & terhadap konstruk lainnya. Hasil uji \\
\hline & & & & & validitas deskriminan dengan metode cross \\
\hline \multirow{2}{*}{\multicolumn{5}{|c|}{$\begin{array}{l}\text { Model mempunyai discriminant } \\
\text { validity yang baik jika nilai kuadrat AVE }\end{array}$}} & loading indikator dapat dilihat pada Tabel \\
\hline & & & & & \\
\hline
\end{tabular}

masing-masing konstruk eksogen (nilai pada diagonal) melebihi korelasi antara konstruk tersebut dengan konstruk lainnya (nilai di bawah diagonal). Hasil pengujian discriminant validity diperoleh sebagai berikut :
Tabel 6. Hasil Uji Validitas Deskriminan Metode Fornell Larcker

\begin{tabular}{llcccc}
\hline & & INS & KSDM & MOT & SP \\
\hline - & INS & 0.941 & & & \\
\hline - & KSDM & 0.778 & 0.954 & & \\
\hline - & MOT & 0.834 & 0.797 & 0.951 & \\
\hline - & SP & 0.812 & 0.762 & 0.870 & 0.949 \\
\hline
\end{tabular}

Sumber : data diolah (2021)

Hasil uji validitas deskriminan pada 
Tabel 7. Hasil Uji Validitas Deskriminan dengan Metode Cross Loading Indikator

\begin{tabular}{|c|c|c|c|c|}
\hline $\begin{array}{c}\text { Indi } \\
\text { kato } \\
\mathbf{r}\end{array}$ & $\begin{array}{l}\text { Insent } \\
\text { if } \\
\text { (INS) }\end{array}$ & $\begin{array}{c}\text { Kompetensi } \\
\text { SDM } \\
\text { (KSDM) }\end{array}$ & $\begin{array}{c}\text { Motivasi } \\
\text { Kerja } \\
\text { (MOT) }\end{array}$ & $\begin{array}{c}\text { Sarana } \\
\text { Pendukung } \\
\text { (SP) }\end{array}$ \\
\hline $\begin{array}{c}\text { INS } \\
1\end{array}$ & 0.940 & 0.659 & 0.737 & 0.659 \\
\hline $\begin{array}{c}\text { INS } \\
2\end{array}$ & 0.894 & 0.769 & 0.753 & 0.671 \\
\hline $\begin{array}{c}\text { INS } \\
3\end{array}$ & 0.947 & 0.716 & 0.705 & 0.751 \\
\hline $\begin{array}{c}\text { INS } \\
4\end{array}$ & 0.967 & 0.750 & 0.854 & 0.831 \\
\hline $\begin{array}{c}\text { INS } \\
5\end{array}$ & 0.956 & 0.762 & 0.854 & 0.882 \\
\hline SP1 & 0.711 & 0.640 & 0.766 & 0.914 \\
\hline SP2 & 0.800 & 0.769 & 0.869 & 0.970 \\
\hline SP3 & 0.762 & 0.688 & 0.819 & 0.963 \\
\hline SP4 & 0.777 & 0.751 & 0.803 & 0.926 \\
\hline SP5 & 0.796 & 0.760 & 0.862 & 0.969 \\
\hline $\begin{array}{c}\text { KSD } \\
\text { M1 }\end{array}$ & 0.753 & 0.941 & 0.783 & 0.735 \\
\hline $\begin{array}{c}\text { KSD } \\
\text { M2 }\end{array}$ & 0.748 & 0.941 & 0.776 & 0.731 \\
\hline $\begin{array}{c}\text { KSD } \\
\text { M3 }\end{array}$ & 0.730 & 0.933 & 0.743 & 0.739 \\
\hline $\begin{array}{c}\text { KSD } \\
\text { M4 }\end{array}$ & 0.738 & 0.978 & 0.746 & 0.708 \\
\hline $\begin{array}{c}\text { KSD } \\
\text { M5 }\end{array}$ & 0.743 & 0.976 & 0.752 & 0.722 \\
\hline $\begin{array}{c}\text { MO } \\
\text { T1 }\end{array}$ & 0.778 & 0.765 & 0.968 & 0.841 \\
\hline $\begin{array}{c}\text { MO } \\
\text { T2 }\end{array}$ & 0.829 & 0.789 & 0.981 & 0.830 \\
\hline $\begin{array}{c}\text { MO } \\
\text { T3 }\end{array}$ & 0.822 & 0.801 & 0.983 & 0.859 \\
\hline $\begin{array}{c}\text { MO } \\
\text { T4 }\end{array}$ & 0.759 & 0.671 & 0.848 & 0.763 \\
\hline $\begin{array}{c}\text { MO } \\
\text { T5 }\end{array}$ & 0.774 & 0.757 & 0.966 & 0.837 \\
\hline
\end{tabular}

Sumber : data diolah (2021)

Berdasarkan hasil uji validitas deskriminan pada tabel di atas, dapat dilihat bahwa seluruh indikator memiliki indikator tertinggi pada konstruknya bukan pada konstruk lain sehingga dapat dinyatakan bahwa seluruh indikator telah memenui persyaratan validitas deskriminan, sebagai contoh indikator SP1 memiliki cross loading 0,914 terhadap konstruknya (Sarana Pendukung), sedangkan terhadap konstruk lainnya cross loading SP1 lebih rendah yaitu sebesar 0,640 terhadap kompetensi SDM (KSDM) dan sebesar 0,766 terhadap konstruk Motivasi
(MOT) validitas deskriminan konstruk SP1 terpenuhi.

Berdasarkan hasil kedua metode pengujian validitas deskriminan tersebut maka dapat disimpulkan bahwa outer model PLS telah memenuhi kriteria validitas deskriminan yang dipersyaratkan.

b. Pengujian Reliabilitas Konstruk

Reliabilitas konstruk dapat dinilai dari nilai crombachs Alpha dan nilai Composite Reliability dari masing-masing konstruk. Nilai composite reliability dan crombachs alpha yang disarankan adalah lebih dari 0,7.

Hasil analisis reliabilitas konstruk dengan melihat nilai crombachs alpha dan composite reliability seluruh konstruk juga telah melebihi 0,7 hal ini menunjukkan bahwa seluruh konstruk telah memenuhi reliabilitas yang dipersyaratkan, sehingga dapat disimpulkan bahwa seluruh konstruk reliabel.

Tabel 8 Hasil Uji Reliabilitas Komposit

\begin{tabular}{clcc}
\hline Variabel & $\begin{array}{c}\text { Cronbach's } \\
\text { Alpha }\end{array}$ & $\begin{array}{c}\text { Composite } \\
\text { Reliability }\end{array}$ \\
\hline$\bullet$ & INS & 0.968 & 0.975 \\
\hline$\bullet$ & SP & 0.972 & 0.978 \\
\hline$\bullet$ & KSDM & 0.975 & 0.981 \\
\hline$\bullet$ & MOT & 0.973 & 0.979 \\
\hline
\end{tabular}

\section{Pengujian Inner Model}

Pengujian inner model meliputi penilaian terhadap goodness of fit model struktural, penilaian terhadap koefisien jalur, uji signifikansi pengaruh parsial variabel eksogen terhadap variabel endogen dan perhitungan koefisien determinasi. Hasil pengujian pada tahap ini dapat digunakan untuk menguji hipotesis penelitian.

a. Penilaian Goodness of fit model Struktural

Pada tahap pengujian model struktural, sebelum dilakukan pengujian model struktural, model terlebih dahulu diuji kelayakannya dengan melihat nilai $R$ square dan nilai $Q$ square model.

Nilai $R$ square model menunjukkan kekuatan prediksi model dilihat dari kekuatan variabel eksogen dalam memprediksi variabel endogen. Nilai $R$ square Motivasi Kerja yaitu 
0,821 dengan kriteria Kuat/Strong Model. Oleh karena nilai $R$ square variabel endogen telah melebihi 0,67 maka model dinyatakan kuat dalam memprediksi hubungan antar variabel dalam model.

Nilai $Q$ square dikategorikan dalam 3 kategori yaitu kecil, sedang dan besar, nilai $Q$ square sebesar 0,02 dinyatakan kecil, nilai $\mathrm{Q}$ square senbesar 0,15 dinyatakan sedang dan nilai $\mathrm{Q}$ square sebesar 0,35 dinyatakan besar.

Tabel 9 Nilai Q square

\begin{tabular}{lccc}
\hline Variabel & SSO & SSE & $\begin{array}{c}\mathbf{Q}^{\mathbf{2}}(=\mathbf{1 -} \\
\text { SSE/SSO) }\end{array}$ \\
\hline INS & 370.000 & 370.000 & \\
\hline KSDM & 370.000 & 370.000 & \\
\hline MOT & 370.000 & 99.482 & 0.731 \\
\hline SP & 370.000 & 370.000 & \\
\hline
\end{tabular}

Perhitungan $Q$ square pada Tabel 9 menunjukkan bahwa nilai $Q$ square variabel motivasi kerja adalah sebesar 0,731 , oleh karena $Q$ Square model telah melebihi 0,35 maka dapat dinyatakan bahwa model PLS sangat baik karena memiliki predictive relevance yang besar sehingga layak digunakan untuk menguji hipotesis penelitian.

Selain dengan melihat nilai $R$ square dan $Q$ square, kesesuaian model PLS dan data yang dianalisis juga dapat dilihat dari nilai SRMR. Model dinyatakan perfect fit jika SRMR model $<0,08$ dan model dinyatakan fit jika SRMR model $<0,10$.

Tabel 10. SRMR Model

\begin{tabular}{ccc}
\hline Fit Parameter & Nilai & Kriteria \\
\hline SRMR & 0.052 & Perfect fit \\
\hline
\end{tabular}

Berdasarkan hasil analisis pada Tabel 10 hasil analisis menunjukkan bahwa nilai SRMR model sebesar 0,052. Oleh karena SRMR model $<0,08$ maka dinyatakan bahw amodel perfect fit dalam memprediksi pengaruh antar variabel dalam model.

Berdasarkan hasil evaluasi kelayakan model dengan melihat nilai $R$ square, $Q$ square dan SRMR model tersebut maka dapat disimpulkan bahwa model PLS layak digunakan untuk menguji hipotesis penelitian.

b. Pengujian Pengaruh Parsial

Uji signifikansi pengaruh langsung digunakan untuk menguji pengaruh parsial variabel eksogen terhadap variabel endogen. Oleh karena penelitian ini menggunakan hipotesis dua arah (two tail), maka hipotesis yang digunakan dalam pengujian ini adalah sebagai berikut :

- Ho : variabel eksogen tidak berpengaruh terhadap variabel endogen

- Ha : variabel eksogen berpengaruh terhadap variabel endogen

Oleh karena hipotesis penelitian merupakan hipotesis 1 arah, maka Ho ditolak dan disimpulkan bahwa variabel eksogen berpengaruh signifikan terhadap variabel endogen jika nilai $\mathrm{P}$ value $<0,05$ dan $\mathrm{t}$ hitung $>1,65$, sedangkan jika nilai $p$ value $>0,05$ dan t hitung $<1,65$ maka Ho tidak ditolak dan disimpulkan bahwa variabel eksogen tidak berpengaruh terhadap variabel endogen.

Hasil uji signifikansi tersebut selanjutnya juga dapat diketahui arah hubungan pengaruh variabel eksogen terhadap endogen. Arah hubungan tersebut dapat diketahui dari koefisien jalur pada masing - masing jalur. Apabila nilai koefisien jalur bertanda positif maka pengaruh eksogen terhadap endogen adalah searah, sedangkan jika koefisien jalur negatif maka pengaruh eksogen terhadap endogen adalah berlawanana arah. Hasil estimasi model sebagai acaun untuk menguji hipotesis dalam penelitian ini dapat dilihat pada Gambar 2 berikut: 


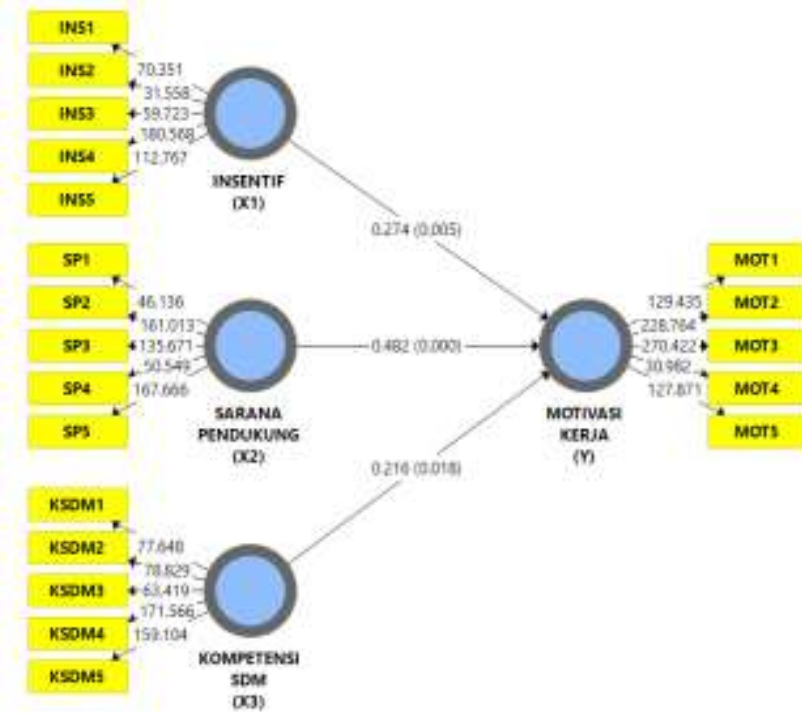

\section{Gambar 2. Hasil estimasi model PLS Bootstrapping}

Berdasarkan hasil estimasi model PLS dengan teknik bootstrapping di atas, dapat dilihat bahwa seluruh jalur signifikan dengan nilai $p$ value $<0,05$. Hasil uji signifikansi pengaruh langsung ini selengkapnya dapat dilihat pada tabel 4.16 berikut:

Tabel 11 Hasil Pengujian Pengaruh Parsial

\begin{tabular}{lccc}
\hline \multicolumn{1}{c}{ Path } & $\begin{array}{c}\text { Path } \\
\text { Coeff }\end{array}$ & $\begin{array}{c}\text { T } \\
\text { Statistic } \\
\text { s }\end{array}$ & $\begin{array}{c}\text { P } \\
\text { Value } \\
\text { s }\end{array}$ \\
\hline - INS -> MOT & 0.274 & 2.600 & 0.005 \\
\hline - SP -> MOT & 0.482 & 4.433 & 0.000 \\
\hline $\begin{array}{l}\text { - KSDM -> } \\
\text { MOT }\end{array}$ & 0.216 & 2.112 & 0.018 \\
\hline
\end{tabular}

Sumber : Hasil Pengolahan Data (2021)

Berdasarkan hasil pengujian hipotesis, maka diperoleh hasil pengujian sebagai berikut:

1. Jalur INS $\rightarrow$ MOT

Pada jalur yang menunjukkan hubungan pengaruh insentif terhadap motivasi kerja, nilai $p$ value yang diperoleh adalah sebesar 0,005 dengan $t$ statistik sebesar 2,600 dan koefisien jalur bertanda positif sebesar 0,274 . Oleh karena nilai $p$ value jalur $<0,05, \mathrm{t}$ statistik > 1,65 dan koefsien jalur bertanda positif maka dapat disimpulkan bahwa insentif berpengaruh positif dan signifikan terhadap motivasi kerja, hal ini menunjukkan bahwa semakin baik pemberian insentif kepada pegawai maka semakin tinggi motivasi kerja pegawai.

2. Jalur SP $\rightarrow$ MOT

Pada jalur yang menunjukkan hubungan pengaruh sarana pendukung terhadap motivasi kerja, nilai $\mathrm{p}$ value yang diperoleh adalah sebesar 0,000 dengan $\mathrm{t}$ statistik sebesar 4,433 dan koefisien jalur bertanda positif sebesar 0,482 . Oleh karena nilai $\mathrm{p}$ value jalur $<0,05, \mathrm{t}$ statistik $>1,65$ dan koefsien jalur bertanda positif maka dapat disimpulkan bahwa sarana pendukung berpengaruh positif dan signifikan terhadap motivasi kerja, hal ini menunjukkan bahwa semakin baik sarana pendukung pegawai maka semakin tinggi motivasi kerja pegawai.

3. Jalur KSDM $\rightarrow$ MOT

Pada jalur yang menunjukkan hubungan pengaruh kompetensi SDM terhadap motivasi kerja, nilai $\mathrm{p}$ value yang diperoleh adalah sebesar 0,018 dengan $\mathrm{t}$ statistik sebesar 2,112 dan koefisien jalur bertanda positif sebesar 0,216 . Oleh karena nilai $p$ value jalur < $0,05, \mathrm{t}$ statistik > 1,65 dan koefsien jalur bertanda positif maka dapat disimpulkan bahwa kompetensi SDM berpengaruh positif dan signifikan terhadap motivasi kerja, hal ini menunjukkan bahwa semakin baik kompetensi pegawai maka semakin tinggi motivasi kerja pegawai.

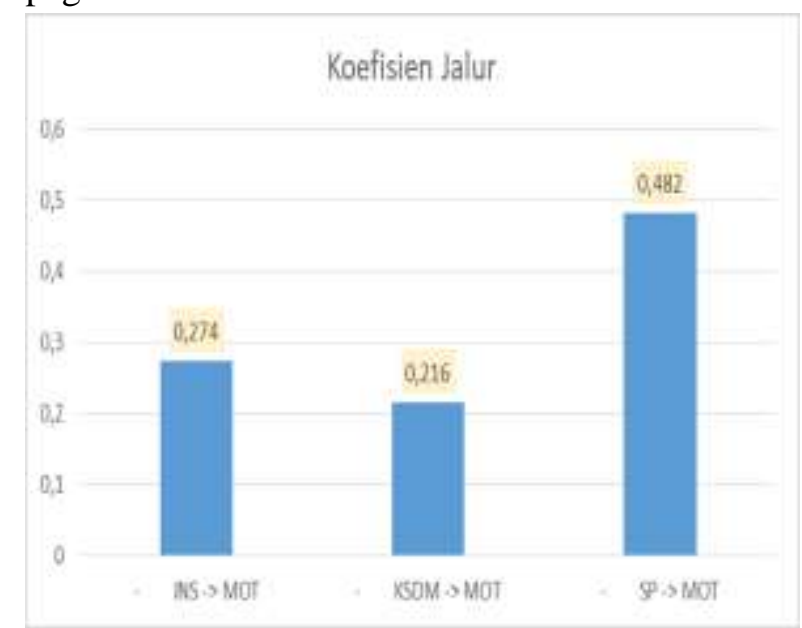

Gambar 3. Evaluasi Koefisien Jalur

Hasil evaluasi koefisien jalur pada grafik di atas menunjukkan bahwa koefisien jalur insentif terhadap motivasi kerja adalah 
0,274, nilai koefisien jalur kompetensi SDM terhadap motivasi kerja adalah 0,216 dan koefisien jalur sarana pendukung terhadap motivasi kerja adalah 0,482, hal ini menunjukkan bahwa saran pendukung merupakan faktor yang paling berpengaruh terhadap tinggi rendahnya motivasi kerja pegawai.

c. Koefisien Determinasi ( $R$ Square)

Koefisien determinasi menunjukkan besar pengaruh variabel eksogen terhadap variabel endogen. Pada analisis PLS, koefisien determinasi dilihat dari nilai adjusted $R$ Square dengan nilai antara $0 \begin{array}{lll}0 & -1\end{array}$. Semakin tinggi adjusted $R$ square maka semakin tinggi besar kontribusi variabel eksogen terhadap endogen.

Tabel 12 Koefisien Determinasi

\begin{tabular}{ccc}
\hline & R Square & $\begin{array}{c}\text { R Square } \\
\text { Adjusted }\end{array}$ \\
\hline Motivasi & 0.821 & 0.813 \\
\hline
\end{tabular}

Sumber : data diolah (2021)

Berdasarkan hasil analisis pada tabel di atas, diperoleh hasil bahwa nilai adjusted $R$ square variabel motivasi kerja adalah sebesar $81,3 \%$, hal ini berarti bahwa $81,3 \%$ variansi motivasi kerja dipengaruhi oleh insentif, sarana pendukung dan kompetensi SDM, sedangkan sisanya sebesar 19,7\% variansi motivasi kerja pegawai dipengaruhi faktor lain di luar insentif, sarana pendukung dan kompetensi SDM.

d. Pengujian Pengaruh Simultan

Setelah dilakukan pengujian terhadap pengaruh parsial, selanjutnya dapat dilakukan pengujian pengaruh simultan. Hipotesis pengujian yang digunakan dalam pengujian pengaruh simultan ini adalah sebagai beriktu :

- Ho : Tidak terdapat pengaruh simultan insentif, sarana pendukung dan kompetensi SDM terhadap motivasi kerja pegawai

- Ha : Terdapat pengaruh simultan insentif, sarana pendukung dan kompetensi SDM terhadap motivasi kerja pegawai

Dengan taraf signifikansi 5\% maka Ho ditolak jika nilai $\mathrm{F}$ hitung $>\mathrm{F}$ tabel. Dengan melihat Tabel F, untuk jumlah sampel sebanyak 74 responden, dengan jumlah variabel (bebas dan terikat ) sebanyak 4 , maka nilai $\mathrm{F}$ tabel pada taraf signifikansi $5 \%$ adalah sebesar 2,503.

Untuk memperoleh nilai $\mathrm{F}$ hitung, diperlukan perhitunagn dengan melibatkan nilai $R$ Square. Nilai $R$ square yang diperoleh hasil analisis PLS adalah 0,813 .

Nilai F hitung sebesar 74,996, oleh karena nilai $\mathrm{F}$ hitugn > F tabel, maka Ho ditolak dan disimpulkan bahwa terdapat pengaruh simultan yang signifikan variabel insentif, sarana pendukung dan kompetensi SDM terhadap motivasi kerja pegawai.

e. Persamaan Struktural

Persamaan struktural dapat dibentuk dari koefisien jalur masing-maisng eksogen dan nilai error pengukuran yang dapat diperoleh dari rumus yang melibatkan nilai $\mathrm{R}$ square model. Hasil analisis PLS dalam penelitian ini menunjukkan nilai $\mathrm{R}$ square sebesar 0,813 , berdasarkan nilai $\mathrm{R}$ suqare tersebut diperoleh hasil perhitungan error yaitu 0,432 .

\section{Pengujian Hipotesis}

Berdasarkan hasil pengujian pengaruh langsung dan tidak langsung pada hasil analisis PLS di atas, maka berikut ini adalah ringkaan hasil pengujian hipotesis yang telah dinyatakan dalam penelitian ini.

\section{Tabel 13 Ringkasan Hasil Pengujian}

\section{Hipotesis}

\begin{tabular}{rlcc}
\hline No & \multicolumn{1}{c}{ Hipotesis } & Hasil & Kesimpulan \\
\hline $\mathbf{1}$ & Insentif & Path coeff & Diterima \\
& berpengaruh & $=0,274 ; \mathrm{t}$ & (accepted) \\
& positif & stat $=$ & \\
& terhadap & 2,$600 ; \mathrm{p}$ & \\
& motivasi kerja & value $=$ & \\
& & 0,005 & \\
$\mathbf{2}$ & Sarana & Path Coeff & Diterima \\
& pendukung & $=0,216 ; \mathrm{t}$ & (accepted) \\
& berpengaruh & stat $=$ & \\
& positif & 2,$112 ; \mathrm{p}$ & \\
& terhadap & value $=$ & \\
& motivasi kerja & 0,018 & \\
3 & Kompetensi & Path Coeff & Diterima \\
& SDM & $=0,482 ; \mathrm{t}$ & (accepted) \\
& berpengaruh & stat $=$ & \\
& positif & 4,$433 ; \mathrm{p}$ & \\
terhadap & value $=$ &
\end{tabular}




\begin{tabular}{llcc} 
motivasi kerja & 0,000 & \\
Insentif, sarana & & $\begin{array}{c}\text { Diterima } \\
\text { (accepted) }\end{array}$ \\
pendukung dan & F hitung & \\
kempetensi SDM & $=74,996$ & \\
secara simultan & $>$ F Tabel & \\
berpengaruh & $=2,503$ & \\
terhadap & & \\
motivasi kerja & & \\
\hline
\end{tabular}

Sumber : Hasil Pengolahan Data (2021)

\section{Pembahasan \\ Pengaruh Insentif Uang Makan terhadap Motivasi Kerja}

Berdasarkan Tabel 4.18 diketahui bahwa hipotesis 1 terbukti dan disimpulkan bahwa insentif uang makan berpengaruh positif dan signifikan terhadap motivasi kerja. Temuan ini menunjukkan bahwa semakin baik pemberian insentif uang makan maka semakin tinggi motivasi kerja pegawai PT. Angkasa Pura II (Persero) unit ARFF Bandar Udara Internasional Kualanamu. Hal tersebut sejalan dengan hasil penelitian terkait yaitu insentif berpengaruh terhadap motivasi kerja yang mana semakin meningkat insentif diberikan maka semakin tinggi motivasi kerja pegawai (Barusman \& Amelia, 2021; Nurmansyah, 2019). Apabila peningkatan insentif tidak ada maka motivasi kerja pegawai akan konstan, sebaliknya jika insentif mengalami peningkatan maka motivasi kerja juga meningkat (Barusman \& Amelia, 2021).

Insentif adalah salah satu sarana penting untuk memotivasi pegawai agar dapat bekerja dengan kemampuan yang maksimal (Nurmansyah, 2019). Uang makan merupakan bentuk dari material incentive yang digunakan untuk memuaskan kebutuhan ekonomi pegawai (Sinaga, 2020). Dapat disimpulkan bahwa uang makan merupakan insentif yang dikeluarkan PT. Angkasa Pura II (Persero) sebagai kesejahteraan pegawai sehingga dapat meningkatkan motivasi kerja pegawai khususnya di unit ARFF Bandar Udara Kualanamu.

\section{Pengaruh Sarana Pendukung terhadap Motivasi Kerja}

Hipotesis 2 terbukti dan disimpulkan bahwa sarana pendukung berpengaruh positif dan signifikan terhadap motivasi kerja (Tabel 4.18). Hal ini menunjukkan bahwa semakin baik sarana pendukung maka semakin tinggi motivasi kerja pegawai. Hasil penelitian ini sejalan dengan hasil penelitian terkait yang menyatakan bahwa sarana pendukung berpengaruh terhadap motivasi kerja yang mana semakin baik sarana pendukung tersedia maka semakin tinggi motivasi kerja pegawai (Anggrainy et al., 2018; Maryadi, 2016; Zatnika \& Ilmaniati, 2018).

Pencapaian tujuan perusahaan memerlukan sarana pendukung atau fasilitas yang sesuai dengan bidang perusahaan. Adanya fasilitas yang nyaman dalam bekerja maka motivasi kerja pegawai tinggi (Maryadi, 2016). Sarana pendukung yang disediakan perusahaan PT. Angkasa Pura II (Persero) susah sesuai dengan kebutuhan pegawai khususnya di unit ARFF Bandar Udara Kualanamu sehingga motivasi kerja juga tinggi.

\section{Pengaruh Kompetensi SDM terhadap Motivasi Kerja}

Hipotesis 3 terbukti dan disimpulkan bahwa kompetensi SDM berpengaruh positif dan signifikan terhadap motivasi kerja (Tabel 4.18). Hal ini menunjukkan bahwa semakin baik kompetensi SDM maka semakin tinggi motivasi kerja pegawai PT. Angkasa Pura II (Persero) unit ARFF Bandar Udara Internasional Kualanamu. Hasil penelitian ini sejalan dengan hasil penelitian terkait yang meyatakan bahwa kompetensi SDM berpengaruh terhadap motivasi kerja, yaitu semakin baik kompetensi SDM maka semakin tinggi motivasi kerja pegawai (Ahmad \& Marwan, 2015; Firmansyah, 2020; Tejo \& Machasin, 2015).

Kompetensi merupakan variabel utama yang harus dimiliki oleh seorang pegawai sehingga dapat menyelesaikan pekerjaannya sesuai target yang telah ditentukan perusahaan 
(Basori et al., 2017). Hasil penelitian ini menunjukkan bahwa kompetensi SDM yang dimiliki pegawai PT. Angkasa Pura II (Persero) sudah sesuai dengan bidangnya khususnya di unit ARFF Bandar Udara Internasional Kualanamu sehingga mempengaruhi motivasi kerjanya.

\section{Insentif, Sarana Pendukung dan Kompetensi SDM Secara Simultan terhadap Motivasi Kerja}

Hipotesis 4 terbukti dan disimpulkan bahwa insentif, sarana pendukung dan kompetensi SDM secara simultan berpengaruh terhadap motivasi kerja (Tabel 4.18). Hal ini menunjukkan bahwa semua variabel (insentif uang makan, sarana pendukung dan kompetensi SDM) memiliki pengaruh yang sama terhadap motivasi kerja pegawai PT. Angkasa Pura II (Persero) unit ARFF Bandar Udara Internasional Kualanamu.

Temuan ini menunjukkan bahwa dengan semakin baiknya insentif dan sarana pendukung yang diberikan oleh perusahaan terhadap pegawainya serta pegawai yang berkompeten sesuai dengan bidang kerjanya maka motivasi kerja pegawai akan semakin meningkat. Peningkatan motivasi kerja pegawai yang positif ini akan memberi efek baik bagi pengembangan dan kemajuan perusahaan.

\section{KESIMPULAN DAN SARAN}

Kesimpulan yang diperoleh dari hasil penelitian ini adalah sebagai berikut: 1 . Insentif berpengaruh positif dan signifikan terhadap motivasi kerja, hal ini menunjukkan bahwa semakin baik pemberian insentif kepada pegawai maka semakin tinggi motivasi kerja pegawai; 2. Sarana pendukung berpengaruh positif dan signifikan terhadap motivasi kerja, hal ini menunjukkan bahwa semakin baik saran pendukung pegawai maka semakin tinggi motivasi kerja pegawai; 3 . Kompetensi SDM berpengaruh positif dan signifikan terhadap motivasi kerja, hal ini menunjukkan bahwa semakin baik kompetensi pegawai maka semakin tinggi motivasi kerja pegawai; 4.
Insentif, sarana pendukung, kompetensi SDM secara simultan berpengaruh terhadap motivasi kerja pegawai. Insentif, sarana pendukung, dan kompetensi SDM memiliki kontribusi yang besar terhadap peningkatan motivasi kerja pegawai.

Saran yang dapat disampaikan dari penelitian ini: (1) Insentif; perusahaan sebaiknya memberi insentif secara tepat waktu dan sesuai dengan ketentuan yang berlaku, (2) Sarana Pendukung; perusahaan harus selalu mengevaluasi kelengkapan sarana pendukung pekerjaan pegawai sehingga motivasi kerja dapat optimal, (3) Kompetensi SDM; perusahaan selalu melakukan peninjauan terhadap komptensi SDM nya dan memberikan pelatihan atau training, (4) Motivasi Kerja; berdasarkan penelitian ini, perusahaan harus lebih memotivasi pegawai terutama pada aspek penghargaan terhadap prestasi kerja dan peluang untuk peningkatan karir.

\section{REFERENSI}

Ahmad, M., \& Marwan. (2015). Pengaruh Kompetensi, Kompensasi dan Lingkungan Kerja Terhadap Motivasi Kerja pada Pegawai Kantor Camat di Kota Sungai Penuh. Jurnal Riset Manajemen Dan Publik, 1(1), 1-11.

Alhudhori, M., Adriani, E., MS, M. Z., \& Albetris, A. (2019). Pengaruh Gaya Kepemimpinan dan Insentif terhadap Motivasi Serta Dampaknya terhadap Kinerja Pegawai Dinas Peternakan dan Perikanan Kabupaten Bungo. Ekonomis: Journal of Economics and Business, 3(2), 177.https://doi.org/10.33087/ekonomis. v3i2.79

Anggrainy, I. F., Darsono, N., \& Putra, R. I. (2018). Pengaruh Fasilitas Kerja, Disiplin Kerja Dan Kompensasi Terhadap Motivasi Kerja Implikasinya Pada Prestasi Kerja Pegawai Negeri Sipil Badan Kepegawaian Pendidikan 
Dan Pelatihan Provinsi Aceh. Jurnal Magister Manajemen, 2(1), 1-10.

Barusman, M., \& Amelia, E. (2021). Pengaruh Insentif Terhadap Motivasi Kerja di Auto 2000 Raden Intan Bandar Lampung. 3-4.

Basori, M. A. N., Prahiawan, W., \& Daenulhay. (2017). Pengaruh Kompetensi Karyawan dan Lingkungan Kerja Terhadap Kinerja Karyawan Melalui Motivasi Kerja Sebagai Variabel Intervening (Studi Pada PT. Krakatau Bandar Samudera). Jurnal Riset Bisnis Dan Manajemen Tirtayasa, 1(2), 149-158.

Bohari, Ansar, \& Tamrin, M. (2019). Pengaruh Kompensasi, Sarana Prasarana Melalui Motivasi Kerja Terhadap Kinerja Petugas Kebersihan pada Dinas Lingkungan Hidup dan Kehutanan Kabupaten Bulukumba. YUME : Journal of Management, 2(3).

Changgriawan, G. S. (2017). Pengaruh Kepuasan Kerja dan Motivasi Kerja Terhadap Kinerja Karyawan One Way Production. Jurnal Agora, 5(3), 1-7.

Firmansyah, A. D. (2020). Pengaruh Kompetensi Terhadap Kinerja Pegawai Pada Badan Kepegawaian Dan Pengembangan Sumber Daya Manusia Kota Tasikmalaya Kepegawaian dan Pengembangan Sumber Daya Manusia Kota Tasikmalaya diperlukan. Jurnal Ilmu Administrasi Negara, 8(1), 51-59.

Irianto, Y. N. (2017). Pengaruh

Ketersediaan Sarana Prasarana Kerja Terhadap Kinerja Pegawai Pada Bagian Umum Sekretariat Daerah Kabupaten Fakfak. Jurnal Ekonomi Peluang, XI(1), 155-169.

Jufrizen, \& Hadi, F. P. (2020). Pengaruh Motivasi Kerja Dan Disiplin Kerja Terhadap Kinerja Karyawan. Jurnal
Online Program Studi Pendidikan Ekonomi, $\quad 5(1), \quad 1$. https://doi.org/10.36709/jopspe.v5i1.13 326

Kusuma, Y. W., \& Mashariono, M. (2016). Pengaruh Motivasi Kerja Dan Insentif Terhadap Semangat. Jurnal Ilmu Dan Riset Manajemen, 5(2).

Maryadi. (2016). Pengaruh Gaji, Bonus, dan Fasilitas Terhadap Motivasi Kerja Karyawan pada PT. Bank Sulselbar Kantor Pusat Makassar. Gema Kampus, 11(1), https://doi.org/https://doi.org/10.52049/ gemakampus.v11i1.13

Mustakim, A., Utomo, S. W., \& Murwani, J. (2017). Pengaruh gaji dan insentif terhadap motivasi kerja guru di SMK PGRI I Mejayan tahun 2017. The 9th FIPA: Forum Ilmiah Pendidikan Akauntansi-Universitas PGRI Madiun, 5(September), 19-34.

Mutahir, A., Ujianto, \& Abdurrakhman, M. Z. (2019). Pengaruh Budaya Kerja, Lingkungan Kerja dan Insentif Terhadap Motivasi Kerja dan Kinerja Pegawai pada Kantor Kelurahan Kabupaten Barito Selatan. Kindai, 17(1), 044-054.

Nasution, D. A. D., \& Ramadhan, P. R. (2018). Analisis Pengaruh SDM , Insentif dan Sarana Pendukung terhadap Implementasi SAP Berbasis Akrual pada Pemerintah Provinsi Sumatera Utara. Jurnal Akuntansi Bisnis Dan Publik, 9(1), 207-218.

Nurmansyah, A. (2019). Pengaruh Kebijakan Promosi Jabatan dan Insentif Terhadap Motivasi Kerja Karyawan Pada Politeknik LP3I Bandung. Atrabis: Jurnal Administrasi Bisnis, 5(1), 86-97. https://doi.org/10.38204/atrabis.v5i1.23 
3

Panambunan, R. J. V., Lengkong, V. P. K., \& Trang, I. (2018). Pengaruh Insentif Material , Insentif Non Material Dan Lingkungan Kerja Terhadap Motivasi Kerja Karyawan Pt Bpr Prisma Dana Manado the Effect of Material Incentives, Non Material Incentives and Work. EMBA, 6(4), 3058-3067.

Pattiasina, M., Roring, M., \& Rumawas, W. (2016). Pengaruh Kompetensi Sumber Daya Manusia Terhadap Kinerja Karyawan PT. Bank Tabungan Negara, Tbk. Kantor Cabang Manado. Jurnal Administrasi Bisnis, 4(2). https://doi.org/https://doi.org/10.35797/j ab.4.2.2016.12258.\%p

Permatatiwi, K., Fauzan, R., \& Syukur, M. H. A. (2010). Analisis Pengaruh Insentif pada Program Retail Ready Branch Terhadap Motivasi dan Kinerja Branch Sales Manager PT. Bank Mandiri (Persero) Tbk. Equator Journal of Management and Entrepreneurship, 113.

Prawira, I. (2020). Pengaruh Kompensasi, Kepemimpinan Dan Fasilitas Kerja Terhadap Kepuasan Kerja Pegawai. Maneggio: Jurnal Ilmiah Magister Manajemen, 3(1), 28-40.

https://doi.org/10.30596/maneggio.v3i 1.4681

Rosmaini, R., \& Tanjung, H. (2019). Pengaruh Kompetensi, Motivasi Dan Kepuasan Kerja Terhadap Kinerja Pegawai. Maneggio: Jurnal Ilmiah Magister Manajemen, 2(1), 1-15. https://doi.org/10.30596/maneggio.v2i 1.3366

Sahputra, R., Hafasnuddin, \& Bahri, S. (2017). Pengaruh Kompetensi, Pelatihan dan Fasilitas Terhadap
Motivasi Kerja dan Dampaknya Terhadap Kinerja Teungku pada Lembaga Dayah di Kabupaten Bireuen. Jurnal Ilmiah Manajemen Muhammadiyah Aceh (JIMMA), 7(1), $1-12$.

Sinaga, S. (2020). Peranan Balas Jasa dan Insentif Terhadap Motivasi Kerja pada PT. Sony Gemerlang Medan. Jurnal Darma Agung, 28(1), 132. https://doi.org/10.46930/ojsuda.v28i1. 605

Sopiah, S., \& Sangadji, E. M. (2018). Manajemen Sumber Daya Manusia Strategik. Andi.

Sugiyanto, S., \& Santoso, D. (2018). Analisis Pengaruh Kompetensi, Sarana Pendukung Teknologi Informasi Dan Kepuasan Kerja Sebagai Variabel Intervening Terhadap Kinerja SDM. Jurnal Riset Ekonomi Dan Bisnis, 11(1), 76. https://doi.org/10.26623/jreb.v11i1.10 78

Sugiyono. (2017). Metode Penelitian Kuantitatif, Kualitatif, dan $R \& D$. Alfabeta, CV.

Sulfemi, W. B. (2020). Hubungan Sarana Prasarana Sekolah dengan Motivasi Mengajar Guru di SMA Negeri Pamijahan Kabupaten Bogor. Jurnal Ilmiah Edutecno, 22(1), 1-19.

Sumardjo, M., \& Priansa, D. J. (2018). Managemen Pengembangan Sumber Daya Manusia, Konsep-konsep Kunci. Penerbit Alfabeta Bandung.

Suparyadi, H. (2015). Manajemen Sumber Daya Manusia-Menciptakan Keunggulan Bersaing Kompetensi SDM (I). Penerbit Andi.

Tejo, G. A., \& Machasin, M. (2015). Pengaruh Kompetensi dan Budaya Organisasi Terhadap Motivasi Kerja 
Serta Dampaknya Terhadap Kinerja Personil Bid. Humas Polda Riau. Jurnal Tepak Manajemen Bisnis, 7(3), 437-454.

Zatnika, M., \& Ilmaniati, A. (2018). Analisis Hubungan Lingkungan, Fasilitas, Insentif dan Disiplin Kerja Terhadap Kinerja Karyawan dengan Motivasi Sebagai Variabel Intervening di PT. HDI. Seminar Nasional VII Manajemen \& Rekayasa Kualitas 2018, 1-10. 